\title{
Efficiency of Biological Fertilization and Moringa Extract Application on Cowpea Productivity and Decreasing Mineral Fertilizers El-Koumy, H.M. ${ }^{1}$;M. Nour El-Din ${ }^{2}$ and Dawlat M. N. Ebady ${ }^{2}$ \\ ${ }^{1}$ Vegetable Research Department, Hort. Res. Inst., Agric. Res. Center, Giza, Egypt. \\ ${ }^{2}$ Soil, Water and Environmental Research Institute, ARC, Egypt.
}

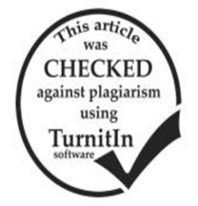

\section{ABSTRACT}

Two field experiments were conducted through summer seasons of 2016 and 2017 to evaluate application of a mixed inoculation (In)biofertilizer (Bradyrhizobiumsp., B. megatherium and B. circulana) and/or moringa leaf extract (MLE) on yield and parameters of cowpea plant. The following parameters were determined: plant height $(\mathrm{cm})$, number of branches/plant, number of leaves/plant, leaf area, fresh weight, dry weight of plant, peduncle number/plant, number of total pods/plant, weight of pods/plant, seeds yield, seeds yield (kg/fed.) and weight of 100 seeds. Also, the percentages of protein, ash, fats and fibers were estimated. The results generally, showed no significant increases for those characteristics due to mixture biological inoculation, although, the mineral fertilizers used with inoculated treatments were very low compared to not inoculated-chemical fertilized control (100\% NPK), inoculation treatments were received $25 \% \mathrm{~N}, 50 \% \mathrm{P}$ and $50 \% \mathrm{~K}$. While the cowpea seeds treatment with moringa leaf extract before planting induced significant increases in these traits over control. Moreover, the application of moringa leaf extract as seeds treatment and foliar spraying were significantly increased these characteristics over not treated (control) and seeds treatments too. The treatment of inoculation with seed treatment and spaying with moringa leaf extract at $25 \% \mathrm{~N}, 50 \% \mathrm{PK}[\operatorname{In}(25 \% \mathrm{~N}+50 \% \mathrm{PK})+\mathrm{S}+\mathrm{M}]$ was the best in this context which attained the highest records in all studied yield components especially seed yield (1263.8 kg/fed.) that represent the highest seed yield. The economic analysis for data of this experiment revealed that this treatment was also the most economic one, whereas exhibited the highest net return (8938.52L.E./fed.) compared to (6309 L.E./fed.) for control treatment (100\% NPK), with a difference about (3130 L.E./fed.).

Keywords: biofertilizer, chemical fertilizer, moringa leaf extract, cowpea plants

\section{INTRODUCTION}

Cowpea (Vigna unguiculata L. Walp) is a multipurpose legume crop, which is used in human food and animal feeding. Moreover, it saves a large amount of nitrogenous fertilizers because of ability to make a symbiotic relationship with Bradyrhizobiumsp., which fix most of the plant needs (Bhuvaneswariet al., 1988 and Bashanndy and El-Shaieny, 2016). In Egypt, about 141830 feddan cultivated with cowpea (Bashandy and El-Shaieny, 2016), and this area will be increased in future due to the continuous population increase.

The biofertilizer microorganisms play an important role in saving chemical fertilizers through biological nitrogen fixation and phosphate and potassium dissolving bacteria, avoiding costs of chemical fertilizers as well as environmental pollution (Oliveira Araujo, 2018).

The use of plant growth promotion hormones became a traditional process especially in horticulture. Phytohormones are naturally occurring signaling molecules, which play an important roles in physiology, development and adaptation of the plant to different stresses (Davies, 2010 and Maishanuet al. 2017) indicated that Moringaoleifera plant leaves rich with plant phytohormones especially zeatin. Bashir et al. (2014) also reported that moringa leaves contain 5 to $10 \%$ protein on average.

The sustainable agriculture requires from us to distance ourselves from synthetic agrochemicals and return to natural materials. Therefore, the present study aimed to investigate the effect of inoculation with biofertilizers and/or application of moringa leaf extract on cowpea growth, yield and economic evaluation.

\section{MATERIALS AND METHODS}

Two field experiments were conducted during the summer seasons of 2016 and 2017 in a private farm at ElShamarka village, Kafr El-Sheikh Governorate, to study the effect of moringa leaves extract application and biological fertilization with mixed inoculation contains Bradyrhizobium sp., B. megatherium and B. circulana on cowpea productivity and decrease the used of mineral fertilizers. Cowpea cv. Kafr El-Sheikh-1 was used, some properties of the experimental soil presented in Table (1).

Table 1. Some physical and chemical properties of the experimental soils.

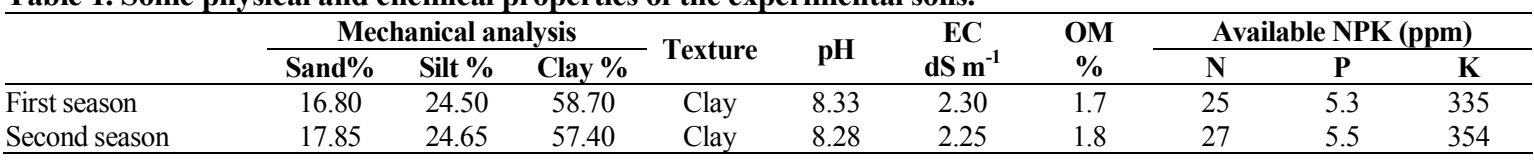

Randomized complete block design was used with four replicates. Six treatments were as follows:

1. $100 \%$ mineral NPK (recommended).

2. $100 \%$ mineral NPK + seed treatment with MLE (3\%)

3. $100 \%$ mineral NPK + seed treatment with MLE + foliar spray with MLE (three times).

4. Inoculation with mixed NPK biofertilizer $(25 \% \mathrm{~N}+$ $50 \% \mathrm{PK})$.

5. Inoculation with mixed NPK biofertilizer $(25 \% \mathrm{~N}+$ $50 \%$ PK) + seed treatment with MLE.
6. Inoculation with mixed NPK biofertilizer $(25 \% \mathrm{~N}+$ $50 \%$ PK) + seed treatment with MLE + MLE foliar spray (three times).

Foliar spray was conducted at 3-4 leaf stage, with 10 days intervals between each spray. In biofertilizer treatments the cowpea seeds mixed with the NPK biofertilizer just before sowing. The seeds were sown at 15 and 10 May for first and second seasons, respectively. Each plot contained four ridges with $6 \mathrm{~m}$ length and $70 \mathrm{~cm}$ width. Seeds were sown on one side of rows at $25 \mathrm{~cm}$ between the hills with two plants/hill. 
The control treatments without inoculation with the mixed biofertilizer take the full dose of NPK chemical fertilizer, which applied as ammonium nitrate $33.5 \%$ (200 $\mathrm{kg} / \mathrm{fed}$ ); calcium super phosphate $15.5 \% \quad \mathrm{P}_{2} \mathrm{O}_{5} \quad(200$ $\mathrm{kg} / \mathrm{fed}$.) as one dose of plowing process; potassium sulphate $48 \% \mathrm{~K}_{2} \mathrm{O}(50 \mathrm{~kg} / \mathrm{fed}$.) added in one dose at flowering stage. Other agricultural processes were conducted as crop recommendations. Samples of the plant were taken after 65 days of sowing for determination of the studied vegetative growth parameters namely plant length $(\mathrm{cm})$, number of leaves/plant, leaf area $\left(\mathrm{cm}^{2}\right)$, fresh and dry weight of plant (g). Also, yield data were taken as number of peduncles/plant, number of pods/plant, weight of peduncles/plant, dry pods/plant, seeds $\left(\mathrm{g} / \mathrm{m}^{2}\right)$, seed yield ( $\mathrm{kg} /$ fed.) and seed index (g/100 seeds). Seed samples were oven dried, crashed and digested according to Cottenieet al. (1982). Nitrogen was determined by micro-kjeldahl method according to Jackson (1958), seed protein content $(\mathrm{N} \times$ 6.25) was calculated fat, ash and fiber content of seed were determined according to AOAC (1984).

\section{Statistical analysis}

Data obtained were subjected to the analysis of variance and treatments means were compared using the Duncan's multiple Range Test (1955).

\section{RESULTS AND DISCUSSION}

Data represented in Table (2) showed that inoculation with the mixed inoculum (bio-NPK) did not show significant increase in cowpea plant length, but a lot amount of fertilizers were saved. On the other hand, seeds which treated with moringa leaf extract exhibited significant positive effect than not treated ones. Moreover, the spray of the plants with moringa leaf extract plus treatment of seeds with it gave higher readings for both cases of inoculation or $100 \%$ chemical fertilization, but the first was superior which attained 54.75 and $63 \mathrm{~cm}$ compared to 50.75 and $54.0 \mathrm{~cm}$ for $100 \%$ NPK at seasons one and two respectively. Number of branches per plant and number of leaves followed the same trend. The treatment of In $(25 \% \mathrm{~N}+50 \% \mathrm{PK})+\mathrm{M}+\mathrm{S}$ gave the highest readings; number of branches represented 5.00 and 5.50 , number of leaves reached 39.75 and 41.0 compared to 3.75 and 4.75 (branches/plant) and 32.25 and 33.5 (leaves/plant) for $100 \%$ NPK treatment at the first and second seasons, respectively. Nevertheless, in $(25 \% \mathrm{~N}+$ $50 \% \mathrm{PK})+\mathrm{M}+\mathrm{S}$ saved a lot amount of chemical fertilizers $75 \%$ of nitrogenous fertilizers, $50 \%$ of phosphorus and potassium fertilizers.

Table 2. Effect of biological fertilizationand moringa leaf extract application on some vegetative growth of cowpea plant at age 65 days.

\begin{tabular}{|c|c|c|c|c|c|c|}
\hline \multirow{2}{*}{ Treatments } & \multicolumn{2}{|c|}{ Plant length (cm) } & \multicolumn{2}{|c|}{ No. of branches/plant } & \multicolumn{2}{|c|}{ No. of leaves/ plant } \\
\hline & Season 1 & Season 2 & Season 1 & Season 2 & Season 1 & Season 2 \\
\hline $100 \% \mathrm{NPK}$ & $50.75 \mathrm{c}$ & $54.00 \mathrm{e}$ & $3.75 \mathrm{c}$ & 4.75 & $32.25 \mathrm{e}$ & $33.50 \mathrm{de}$ \\
\hline $100 \% \mathrm{NPK}+\mathrm{M}$ & $52.50 \mathrm{~b}$ & $57.25 \mathrm{c}$ & $4.75 \mathrm{ab}$ & 5.00 & $35.00 \mathrm{~d}$ & $35.25 \mathrm{~cd}$ \\
\hline $100 \% \mathrm{NPK}+\mathrm{M}+\mathrm{S}$ & $55.00 \mathrm{a}$ & $61.00 \mathrm{~b}$ & $4.75 \mathrm{ab}$ & 5.50 & $38.50 \mathrm{~b}$ & $38.00 \mathrm{~b}$ \\
\hline $\operatorname{In}(25 \% \mathrm{~N}+50 \% \mathrm{PK})$ & $51.00 \mathrm{bc}$ & $55.25 \mathrm{~d}$ & $4.00 \mathrm{bc}$ & 4.75 & $32.50 \mathrm{e}$ & $32.75 \mathrm{e}$ \\
\hline $\operatorname{In}(25 \% \mathrm{~N}+50 \% \mathrm{PK})+\mathrm{M}$ & $51.25 \mathrm{bc}$ & $57.75 \mathrm{c}$ & $4.50 \mathrm{abc}$ & 5.00 & $36.75 \mathrm{c}$ & $35.75 \mathrm{c}$ \\
\hline In $(25 \% \mathrm{~N}+50 \% \mathrm{PK})+\mathrm{M}+\mathrm{S}$ & $54.75 \mathrm{a}$ & $63.00 \mathrm{a}$ & $5.00 \mathrm{a}$ & 5.50 & $39.75 \mathrm{a}$ & $41.00 \mathrm{a}$ \\
\hline F-test & $* *$ & $* *$ & $*$ & NS & $* *$ & $* *$ \\
\hline
\end{tabular}

M:Seed treatment with moringa extract $\quad$ S:Foliar spray with moringa extract (3 times)

In: Biofertilizer inoculation $\quad * *$ indicate significant differences at $\mathbf{P}<0.01$ according to $\mathrm{F}$-test.

Values having the same alphabetical letter within each column are not significantly different at 5\% level, according to Duncan's Multiple range test.

Moringa leaf extract application for cowpea seeds significantly increased leaf area $\left(\mathrm{cm}^{2}\right)$, fresh and dry weight of the plant, at both seasons. Moringa leaf extract seed treatment plus foliar spray improved studied traits over seed treatment only, and the differences were significant (Table 3).

Table 3. Effect of biological fertilizationand moringa leaf extract application on leaf area, fresh and dry weight of cowpea plant at age 65 days.

\begin{tabular}{|c|c|c|c|c|c|c|}
\hline \multirow{2}{*}{ Treatments } & \multicolumn{2}{|c|}{ Leaf area $\left(\mathrm{cm}^{2} /\right.$ plant $)$} & \multicolumn{2}{|c|}{ Fresh weight (g/plant) } & \multicolumn{2}{|c|}{ Dry weight (g/plant) } \\
\hline & Season 1 & Season 2 & Season 1 & Season 2 & Season 1 & Season 2 \\
\hline $100 \% \mathrm{NPK}$ & $395.33 \mathrm{c}$ & $411.60 \mathrm{c}$ & $423.25 \mathrm{~d}$ & $447.00 \mathrm{~d}$ & $70.90 \mathrm{c}$ & $76.00 \mathrm{e}$ \\
\hline $100 \% \mathrm{NPK}+\mathrm{M}$ & $410.23 b$ & $527.83 \mathrm{~b}$ & $542.50 \mathrm{c}$ & $573.50 \mathrm{c}$ & $108.95 \mathrm{~b}$ & $103.75 \mathrm{c}$ \\
\hline $100 \% \mathrm{NPK}+\mathrm{M}+\mathrm{S}$ & $551.48 \mathrm{a}$ & $581.00 \mathrm{a}$ & $596.25 \mathrm{~b}$ & $683.25 \mathrm{~b}$ & $119.88 \mathrm{a}$ & $121.63 \mathrm{~b}$ \\
\hline In $(25 \% \mathrm{~N}+50 \% \mathrm{PK})$ & $395.85 \mathrm{c}$ & $413.45 \mathrm{c}$ & $425.25 \mathrm{~d}$ & $449.00 \mathrm{~d}$ & $71.58 \mathrm{c}$ & $80.85 \mathrm{~d}$ \\
\hline $\operatorname{In}(25 \% \mathrm{~N}+50 \% \mathrm{PK})+\mathrm{M}$ & $409.68 \mathrm{~b}$ & $533.85 \mathrm{~b}$ & $548.25 \mathrm{c}$ & $578.00 \mathrm{c}$ & $110.73 \mathrm{~b}$ & $106.93 \mathrm{c}$ \\
\hline $\operatorname{In}(25 \% \mathrm{~N}+50 \% \mathrm{PK})+\mathrm{M}+\mathrm{S}$ & $553.90 \mathrm{a}$ & $587.40 \mathrm{a}$ & $610.75 \mathrm{a}$ & $699.50 \mathrm{a}$ & $122.15 \mathrm{a}$ & $129.40 \mathrm{a}$ \\
\hline F-test & $* *$ & $* *$ & $* *$ & $* *$ & $* *$ & $* *$ \\
\hline
\end{tabular}

M:Seed treatment with moringa extract. $\quad$ S:sFoliar spray with moringa extract (3 times)

In: Biofertilizer inoculation $\quad * *$ indicate significant differences at $P<0.01$ according to F-test.

Values having the same alphabetical letter within each column are not significantly different at 5\% level, according to Duncan's Multiple range test.

Seed treatment in moringa leaf extract with or without foliar spray in presence of inoculation with rhizobia showed the same trend in absence of inoculation. On the other hand, although, inoculation with rhizobia did not attain significant increases in the studied traits, but a lot amount of fertilizers were saved $(75 \% \mathrm{~N}, 50 \% \mathrm{P}$ and $50 \%$
$\mathrm{K})$. The response of the plant was the best to the application of In $(25 \% \mathrm{~N}+50 \% \mathrm{NP})+\mathrm{M}+\mathrm{S}$ treatment, which achieved leaf area about 553.9 and 587.4; fresh weight of the plant, 610.75 and 699.5; dry weigh of the plant, 122.15 and 129.4 compared to the control treatment (100\% NPK) which exhibited leaf area, 395.33 and 411.6; 
fresh weight, 423.25 and 447; dry weight 70.9 and 76 at first and second seasons, respectively.

The recorded data in Table (4) indicated that the treatment of seeds cowpea with moringa leaf extract significantly induced the main yield parameters, namely, number of peduncles/plant, number of pods/plant and dry weight of pods/plant (g/plant) compared to the not treated control. Moreover, the spray with moringa leaf extract three times gave additional increases, whereas, highly improved these studied traits. In addition, the response of the plant to seed treatment only or seed treatment with spray gave positive effect whatever with the rhizobial inoculation or with the not inoculated treatments, but the inoculated treatments attained best positive response.

Table 4. Effect of biological fertilization and moringa leaf extract application on number of peduncle, number of pods and weight of dry pods per cowpea plant.

\begin{tabular}{|c|c|c|c|c|c|c|}
\hline \multirow{2}{*}{ Treatments } & \multicolumn{2}{|c|}{ No. of peduncles/plant } & \multicolumn{2}{|c|}{ No. of pods/plant } & \multicolumn{2}{|c|}{ Weight of dry pods/plant (g) } \\
\hline & Season 1 & Season 2 & Season 1 & Season 2 & Season 1 & Season 2 \\
\hline $100 \% \mathrm{NPK}$ & $11.13 \mathrm{~d}$ & $11.70 \mathrm{~d}$ & $22.50 \mathrm{e}$ & $23.55 \mathrm{c}$ & $33.20 \mathrm{c}$ & $35.20 \mathrm{~d}$ \\
\hline $100 \% \mathrm{NPK}+\mathrm{M}$ & $12.53 \mathrm{c}$ & $12.73 \mathrm{c}$ & $24.00 \mathrm{~d}$ & $24.73 \mathrm{~b}$ & $37.03 \mathrm{~b}$ & $38.90 \mathrm{~b}$ \\
\hline $100 \% \mathrm{NPK}+\mathrm{M}+\mathrm{S}$ & $13.60 \mathrm{~b}$ & $13.53 \mathrm{ab}$ & $26.53 \mathrm{~b}$ & $26.90 \mathrm{a}$ & $39.13 \mathrm{a}$ & $40.33 \mathrm{a}$ \\
\hline In $(25 \% \mathrm{~N}+50 \% \mathrm{PK})$ & $11.38 \mathrm{~d}$ & $11.83 \mathrm{~d}$ & $22.73 \mathrm{e}$ & $23.78 \mathrm{c}$ & $34.10 \mathrm{c}$ & $36.40 \mathrm{c}$ \\
\hline $\operatorname{In}(25 \% \mathrm{~N}+50 \% \mathrm{PK})+\mathrm{M}$ & $12.60 \mathrm{c}$ & $12.93 \mathrm{bc}$ & $24.98 \mathrm{c}$ & $24.80 \mathrm{~b}$ & $36.93 \mathrm{~b}$ & $39.45 \mathrm{~b}$ \\
\hline $\operatorname{In}(25 \% \mathrm{~N}+50 \% \mathrm{PK})+\mathrm{M}+\mathrm{S}$ & $14.10 \mathrm{a}$ & $14.08 \mathrm{a}$ & $27.20 \mathrm{a}$ & $27.33 \mathrm{a}$ & $40.05 \mathrm{a}$ & $40.78 \mathrm{a}$ \\
\hline F-test & $* *$ & $* *$ & $* *$ & $* *$ & $* *$ & $* *$ \\
\hline
\end{tabular}

M:Seed treatment with moringa extract $\quad$ S:Foliar spray with moringa extract (3 times)

In: Biofertilizer inoculation $\quad * *$ indicate significant differences at $P<0.01$, according to F-test.

Values having the same alphabetical letter within each column are not significantly different at $5 \%$ level, according to Duncan's Multiple range test.

On the other hand, the inoculation with rhizobia exhibited increase in the studied traits, but these increases over un-inoculated control were mostly not significant. Although, the inoculation with the seed treatment or seed treatment plus spray with moringa leaf extract attained highly results, and these increases were significant over other studied treatments. This treatment gave 14.1 and 14.08 for peduncle, 27.2 and 27.33 for number of pods/plant; 40.05 and 40.78 for dry weight of pods/plant at first and second seasons, respectively.

The data of the present study revealed the presence of positive influences on cowpea yield components i.e. plant length, number of branches, number of leaves, leaf area, fresh weight, dry weight, number of peduncle pods, number of pods and weight of pods. All these traits obviously improved the use of moringa leaf extract either as seeds treatment or treatment plus foliar spray. Many modern researches confirmed these results (Abdalla, 2013;Maishanu et al. 2017 and DijouhouFowe et al. 2018) concluded that the use of moringa leaf extract enhance plant growth parameters over untreated control. Results of the present study revealed that inoculation with Bradyrhizobium sp. mostly increased plant growth parameters over control without inoculation (100\% NPK), but, mostly, with no significant variations. Junior et al. (2018) found that inoculation of cowpwea plants with Bradyrhizobiumsp. increased biological nitrogen fixation rate and consequently rose plant seed yield. Similarly, Koriret al. (2017) reported that coinoculation with rhizobia and Panibacilluspolymexa increased bean performance and yield treatment. The cowpea seeds with moringa leaf extract significantly increased, seed yield per feddan (kg/feddan) and weight of 100 seeds (Table 5), through both studying seasons. Spray of plants with moringa leaf extract plus seed treatment significantly increased these studied traits over control (Table 5).

On the other hand, theinoculation with the mixed inoculum did not induce increases in these traits, but the benefit was the save of about $75 \% \mathrm{~N}, 50 \% \mathrm{P}$ and $50 \% \mathrm{~K}$ fertilizers without any decreases in the plant yield. The treatment of In $(25 \% \mathrm{~N}+50 \% \mathrm{NP})+\mathrm{M}+\mathrm{S}$ attained the highest records of the studied yield parameters, it gave $312.53,315.95\left(\mathrm{~g} / \mathrm{m}^{2}\right)$ seed yield; 1250.12 and 1263.8 $\mathrm{kg} /$ fed. Seeds yield; 17.5 and 18.37 (weight of 100 seeds at the first and second seasons, respectively.

Table 5. Effect of biological fertilization and moringa leaf extract application on seed yield and seed index of cowpea plants.

\begin{tabular}{lcccccc}
\hline Treatments & \multicolumn{2}{c}{ Seed yield $\left(\mathbf{g} / \mathbf{m}^{2}\right)$} & \multicolumn{2}{c}{ Seed yield $(\mathbf{k g} / \mathbf{f e d}$ ) } & \multicolumn{2}{c}{ Weight of 100 seeds $(\mathbf{g})$} \\
\cline { 2 - 7 } & Season 1 & Season 2 & Season 1 & Season 2 & Season 1 & Season 2 \\
\hline $100 \%$ NPK & $2665.60 \mathrm{c}$ & $271.26 \mathrm{c}$ & $1066.40 \mathrm{c}$ & $1085.05 \mathrm{c}$ & $15.38 \mathrm{c}$ & $16.00 \mathrm{c}$ \\
$100 \% \mathrm{NPK}+\mathrm{M}$ & $283.78 \mathrm{~b}$ & $294.50 \mathrm{~b}$ & $1135.12 \mathrm{~b}$ & $1178.00 \mathrm{~b}$ & $16.68 \mathrm{~b}$ & $17.20 \mathrm{~b}$ \\
$100 \% \mathrm{NPK}+\mathrm{M}+\mathrm{S}$ & $307.78 \mathrm{a}$ & $312.35 \mathrm{a}$ & $1231.12 \mathrm{a}$ & $1249.40 \mathrm{a}$ & $17.50 \mathrm{a}$ & $18.30 \mathrm{a}$ \\
$\mathrm{In}(25 \% \mathrm{~N}+50 \% \mathrm{PK})$ & $268.03 \mathrm{c}$ & $270.33 \mathrm{c}$ & $1072.12 \mathrm{c}$ & $1081.32 \mathrm{c}$ & $15.43 \mathrm{c}$ & $16.20 \mathrm{c}$ \\
In $(25 \% \mathrm{~N}+50 \% \mathrm{PK})+\mathrm{M}$ & $285.20 \mathrm{~b}$ & $297.65 \mathrm{~b}$ & $1140.80 \mathrm{~b}$ & $1190.60 \mathrm{~b}$ & $16.45 \mathrm{~b}$ & $17.35 \mathrm{~b}$ \\
In $(25 \% \mathrm{~N}+50 \% \mathrm{PK})+\mathrm{M}+\mathrm{S}$ & $312.53 \mathrm{a}$ & $315.95 \mathrm{a}$ & $1250.12 \mathrm{a}$ & $1263.80 \mathrm{a}$ & $17.50 \mathrm{a}$ & $18.37 \mathrm{a}$ \\
F-test & $* *$ & $* *$ & $* *$ & $* *$ & $* *$ & $* *$ \\
\hline
\end{tabular}

\begin{tabular}{lc}
\hline M:Seed treatment with moringa extract & S:Foliar spray with moringa extract (3 times) \\
In: Biofertilizer inoculation & $* *$ indicate significant differences at $P<0.01$ respectively according to F-test.
\end{tabular}

In: Biofertilizer inoculation $\quad * *$ indicate significant differences at $\mathrm{P}<\mathbf{0 . 0 1}$ respectively according to $\mathrm{F}$-test.

Values having the same alphabetical letter within each column are not significantly different at 5\% level, according to Duncan's Multiple range test. 
The data of Table (6), recorded protein $\%$, ash $\%$, fat $\%$ and fiber $\%$ for yielded cowpea seeds. The treatment of seeds with moringa leaf extract before planting raised percentages of protein, ash and fats in the produced seeds. Also, the spray with moringa leaf extract plus seed treatment largely increased these traits over seed treatment or not treatment (control), the differences were significant.
While, the inoculation with the mixed inoculum did not affect these parameters. The treatment of $(25 \% \mathrm{~N}, 50 \%$ $\mathrm{PK})+\mathrm{M}+\mathrm{S}$ was the superior in this respect. It exhibited $21.7,22.33 \%$ protein, 5.33 and $5.21 \%$ ash, 1.36 and $1.30 \%$ fats; 9.2 and $9.27 \%$ fiber for first and second seasons, respectively.

Table 6. Effect of biological fertilization and moringa leaf extract application on protein, total ash, fat and fibers percentages of cowpea seeds.

\begin{tabular}{|c|c|c|c|c|c|c|c|c|}
\hline \multirow{2}{*}{ Treatments } & \multicolumn{2}{|c|}{ Protein \% } & \multicolumn{2}{|c|}{ Total ash \% } & \multicolumn{2}{|c|}{ Fat $\%$} & \multicolumn{2}{|c|}{ Fibers \% } \\
\hline & Season 1 & Season 2 & Season 1 & Season 2 & Season 1 & Season 2 & Season 1 & Season 2 \\
\hline $100 \% \mathrm{NPK}$ & $20.73 \mathrm{c}$ & $20.77 \mathrm{c}$ & $4.51 \mathrm{c}$ & $4.60 \mathrm{c}$ & $1.03 \mathrm{c}$ & $1.07 \mathrm{c}$ & $8.82 \mathrm{~b}$ & $8.84 \mathrm{c}$ \\
\hline $100 \% \mathrm{NPK}+\mathrm{M}$ & $21.40 \mathrm{~b}$ & $21.83 \mathrm{~b}$ & $4.88 \mathrm{~b}$ & $4.93 \mathrm{bc}$ & $1.23 \mathrm{ab}$ & $1.23 \mathrm{~b}$ & $8.30 \mathrm{~b}$ & $8.93 \mathrm{~b}$ \\
\hline $100 \% \mathrm{NPK}+\mathrm{M}+\mathrm{S}$ & $21.70 \mathrm{a}$ & $22.37 \mathrm{a}$ & $5.46 \mathrm{a}$ & $5.55 \mathrm{a}$ & $1.37 \mathrm{a}$ & $1.43 \mathrm{a}$ & $9.21 \mathrm{a}$ & $9.26 \mathrm{a}$ \\
\hline $\operatorname{In}(25 \% \mathrm{~N}+50 \% \mathrm{PK})$ & $20.67 \mathrm{c}$ & $21.00 \mathrm{c}$ & $4.50 \mathrm{c}$ & $4.61 \mathrm{c}$ & $1.03 \mathrm{c}$ & $1.07 \mathrm{c}$ & $8.81 \mathrm{~b}$ & $8.83 \mathrm{c}$ \\
\hline $\operatorname{In}(25 \% \mathrm{~N}+50 \% \mathrm{PK})+\mathrm{M}$ & $21.50 \mathrm{ab}$ & $21.90 \mathrm{~b}$ & $4.84 \mathrm{~b}$ & $4.94 \mathrm{bc}$ & $1.23 \mathrm{~b}$ & $1.22 \mathrm{~b}$ & $8.86 \mathrm{~b}$ & $8.93 \mathrm{~b}$ \\
\hline$\underline{\operatorname{In}(25 \% \mathrm{~N}+50 \% \mathrm{PK})+\mathrm{M}+\mathrm{S}}$ & $21.70 \mathrm{a}$ & $22.33 \mathrm{a}$ & $5.33 \mathrm{a}$ & $5.21 \mathrm{ab}$ & $1.36 \mathrm{a}$ & $1.30 \mathrm{ab}$ & $9.20 \mathrm{a}$ & $9.27 \mathrm{a}$ \\
\hline F-test & $* *$ & $* *$ & $* *$ & $* *$ & $* *$ & $* *$ & $* *$ & $* *$ \\
\hline
\end{tabular}

M:Seed treatment with moringa extract $\quad$ S:Foliar spray with moringa extract (3 times)

In: Biofertilizer inoculation $\quad * *$ indicate significant differences at $P<0.01$ according to F-test.

Values having the same alphabetical letter within each column are not significantly different at 5\% level, according to Duncan's Multiple range test.

Data illustrated in Table (7) showed the economic analysis of the studied treatments on cowpea plant under study. The evaluation revealed that all the studied treatments increased the net return (LE/fed.), and the highest net return recorded due to the treatment with in $(25 \% \mathrm{~N}+50 \% \mathrm{PK})+\mathrm{M}+\mathrm{S}$ which attained 15083.52 (L.E/fed.), that increased over $100 \%$ NPK control treatment with 3130 (L.E/fed.).

Table 7. Economic analysis for the response of cowpea plant for moringa leaf extract and biofertilizer application.

\begin{tabular}{lccccccc}
\hline Treatment & $\begin{array}{c}\text { Fixed costs } \\
(\mathbf{L E})\end{array}$ & $\begin{array}{c}\text { Changed } \\
\text { cost (LE) }\end{array}$ & $\begin{array}{c}\text { Total } \\
\text { cost (LE) }\end{array}$ & $\begin{array}{c}\text { Total yield } \\
\text { (kg/fed.) }\end{array}$ & $\begin{array}{c}\text { Value } \\
(\mathbf{L . E})\end{array}$ & $\begin{array}{c}\text { Net return } \\
(\mathbf{L E})\end{array}$ & $\begin{array}{c}\text { Increase or decrease } \\
\text { than control }\end{array}$ \\
\hline $100 \% \mathrm{NPK}$ & 5500 & 1600 & 7100 & 1075.73 & 12908.76 & 5808.76 & \\
$100 \% \mathrm{NPK}+\mathrm{M}$ & 5500 & 1650 & 7150 & 1156.56 & 13878.72 & 6728.72 & 917.2 \\
$100 \% \mathrm{NPK}+\mathrm{M}+\mathrm{S}$ & 5000 & 1695 & 7195 & 1240.20 & 14883.12 & 7688.12 & 1879.36 \\
$\mathrm{In}(25 \% \mathrm{~N}+50 \% \mathrm{PK})$ & 5500 & 545 & 6045 & 1076.72 & 12920.64 & 6875.64 & 1066.88 \\
$\mathrm{In}(25 \% \mathrm{~N}+50 \% \mathrm{PK})+\mathrm{M}$ & 5500 & 595 & 6095 & 1165.70 & 13988.40 & 7893.40 & 2084.64 \\
In $(25 \% \mathrm{~N}+50 \% \mathrm{PK})+\mathrm{M}+\mathrm{S}$ & 5500 & 645 & 6145 & 1256.96 & 15083.52 & 8938.52 & 3129.76 \\
\hline
\end{tabular}

Fixed costs/feddan: land rent (4000 LE), seeds (500 LE), agricultural processes (1000 LE).

Changed costs/feddan: Chemical fertilizers, NPK (1600 LE), moringa leaf extract (50 LE), biofertilizers (45 LE).

Due to the good performance of biofertilizers in improving plant yield and saving a large amounts of chemical fertilizers, the attention was paid by the scientists to exploit beneficial microorganisms for sustainable agriculture - such microorganisms consists of diverse microbes which used as inoculums. These biofertilizer inoculums like PGPR. $\mathrm{N}_{2}$-fixers, phosphate solubilizing bacteria and potassium solubilizing bacteria.Azotobacter is a popular $\mathrm{N}_{2}$-fixing biofertilizer plays an important role in $\mathrm{N}_{2}$-fixation, production of vitamins as thiamin and riboflavin, and plant hormones as indoleacitic acid, gibberellins and cytokinins. In addition, it improves plant growth by enhancing seed germination and advancing rooot architecture as well as inhibition pathogenic microorganisms around the root system (Bhardwajet al., 2014).On the other hand, phosphate solubilizing bacteria are important in phosphorus nutrition by solubilizing unavailable phosphate to be available for plant uptake. The main mechanism of action is lowering rhizosphere $\mathrm{pH}$ through organic and inorganic acids production by the microbe (Anandet al., 2016). In addition, potassium solubilizing bacteria (KSB) contribute in sustainable agriculture through solubilizing potassium minerals e.g. biotite, feldspare, illite, muscovite, orthoclase and mica. KSB can dissolve silicate minerals and release $\mathrm{K}$ through production of organic and inorganic acids,acidolysis, polysacharides, complexolysis, chelation and exchange reaction, hence, good management of KSB can resolve problem of high price of K fertilizers (Etesamiet al., 2007).

Sawleyet al.(2018) found that, cowpea plants treated with moringa leaf extract at one week after planting gave more $(\mathrm{P}<0.5)$ seeds than not treated one . Maishanuet al.(2017)reported thatmoringa leaf extract is rich with numerous of hormones, particularly zeatin that had been reported to increase cowpea yield .Moringa leaf juice also, contains micronutrients in sufficient quantities and suitable proportion that increase growth and yield.

\section{CONCULSION}

Cowpea is a multipurpose feeding plant. The uses of agrochemicals are hazardous on human and the environment. Exploiting an environmental friendly agriculture processes became urgent. The applications of natural hormone like material namely moringa leaf extract surprisingly increased cowpea yield. In addition, biofertilization of the crop with a mixed inoculum contributes in saving a large amount of chemical fertilizers, which lead to the increase of net return (LE/fed.) . 


\section{REFERENCES}

Abdalla, Mona, M. (2013).The potential of Moringaoleifera as a biostimulant in enhancing the growth, biochemical and hormonal contents in rocket (Erucavesicaria sub sp. sativa) plants.In J. Plant Physiol., Biochem. 5(3): 42-49.

Anand, K.; B. Kumari and M.A. Malliek (2016).Phosphate solubilizing microbes: an effective and alternative approach as biofertilizer. International Journal of Pharmacy and Pharmaceuutical Science, 8(2): 37-40.

A.O.A.C. (1984).Official Methods of Analysis. $14^{\text {th }}$ ed., Washington DC: Association of Official Analytical Chemists.

Bashandy, T. and A.A.H. El-Shaieny (2016).Screening of cowpea (Vignaunguiculata L. Walp.) genotypes for salinity tolerance using field evaluation and molecular analysis. J. Agric. Chem. and Biotechn., Mansoura Univ., 7(9): 249-255.

Bashir, K.A.; J.A. Bawa and I. Mohammed (2014). Efficacy of leaf extract of Drumstick tree (Moringaoleifera Lam.) on the growth of local tomato (Lycopersiconesculentum). Journal of Pharmacy and Biological Sceinces, 9(4): 74-79.

Bhardwaj.; D.; M.W. Ansari and R.K. Sahoo (2014). Biofertilizers function as key player in sustainable agriculture by improving soil fertility, plant tolerance and crop productivity. Microbial Cell Factories, 13: 66.

Bhuvaneswari, T.V.; A. P. Lesniak and W.D. Baver (1988).Efficiency of nodule initiation in cowpea and soybean.Plant Physiol, 86: 1210-1215.

Cottenie, A.; M. Verloo; L. Kiekens; G. Velghe and R. Camerlynck (1982).Chemical analysis of plants and soils.Laboratory and Analytical and Agrochemistry State Univ., Ghent. Belgium.

Davies, P.J. (2010). Plant hormones: Biosynthesis signal transduction, Actional $3^{\text {rd }}$ Edition, Kluwer Academic Publishers, Dordrecht, Netherlands.
DjouhouFowe, M.C.; E. Fokou and D. Nwaga (2018). Potential of Moringaoleifera leaf powder and beneficial microorganisms (mycorrhizal fungi and rhizobia) in nodulating plant symbiosis and yield. Sch. J. Agric. Vet. Sci., 5(4); 236-243.

Duncan, D.B. (1955). Multiple range and multiple F-test. Biometrics, 11: 1-42.

Etesami, H.; S. Emami and H.A. Alikhani (2007). Potassium solubilizing bacteria (KSB): Mechanisms, promolion, plant growth and future prospects. A review. Journal of Soil Science and Plant Nutrition, 17(4): 897-909.

Jackson, M.L. (1958). Soil Chemical Analysis.Prentice Hall Inc.

Junior, E.B.S.; V.O. Favero; G.R. Xavie; R.M. Boddey and J.E. Zilli (2018). Rhizobium inoculationof cowpea in BrazillianCerrado increases yields and nitrogen fixation. Agronomy Journal, 110(2): 722-727.

Korir, H.; N.W. Mungai; M. Thuits; Y. Hamba and C. Masso (2017).Co-inoculation effect of rhizobia and growth promoting rhizobacteria on common bean in a low phosphorus soil. Front Plant Sci., 8: 141.

Maishanu, H.M.; M.M. Mohamed; S. Yahaya; A. Yunusa (2017). The use of moringa leaves extract as a plant growth hormone on cowpea (Vigna unguiculata). Path of Science, 3(12): 3001-3006.

Oliveira, Araujo, E.; M. Mauad; H.C. Tadeu; H.A.L. Filho; J.A.F. Silva and J.A. Cardoso (2018). Nutritional status of cowpea plants inoculated with Bradyrhizobiumand Azospirillumbrasilenseassociated with phosphate-fertilization in Amazonian soil. Journal of Experimental Agricultural International, 23(5): 1-13.

Sawley,E.N.K.;F Kaukam and H.Dasmona (2018).Effect of time of application of moringa (Moringa Oleifer L) leaf powder on root-knot nematode (Meloidogyne Spp.) infecting cowpea (Vignaunguiculata L.Walp) .Advances in Agricultural Science, 6(4):32-41.

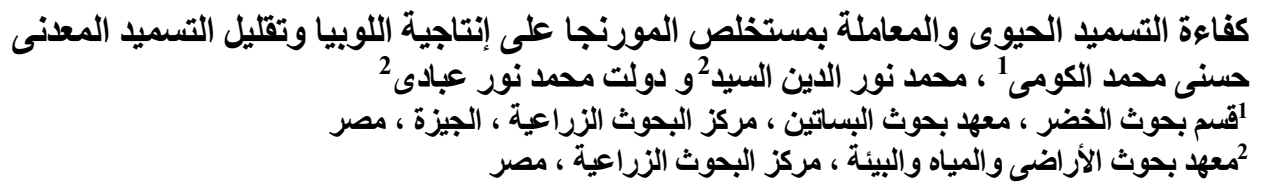

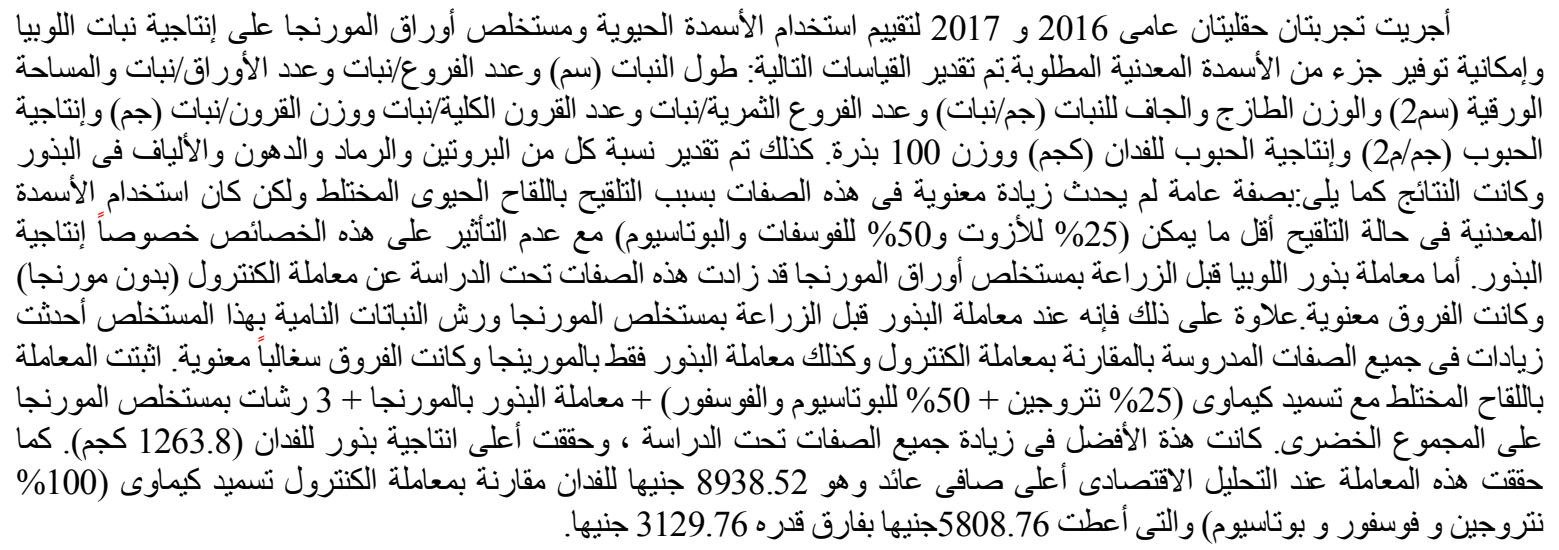

